\title{
Baking at the Front Line, Sleeping with the Enemy: Reflections on Gender and Women's Peace Activism in Israel
}

Hagar Kotef

Columbia University

$\mathrm{O}$ ne day in the summer of 2004, a shift of activists from Checkpoint Watch (CPW) brought to the checkpoint some cookies that one of them had baked earlier that morning. Checkpoint Watch is an allwomen Israeli organization that opposes the Israeli checkpoints in the occupied Palestinian territories and the Israeli 1967 occupation more broadly. Its members conduct routine tours to monitor changes in the deployment of checkpoints and stand in regular shifts at the larger, manned checkpoints in the West Bank. As they spend several hours weekly at specific checkpoints, some activists develop acquaintances with both the soldiers who operate them and the Palestinians who regularly pass through them. Many also stop for coffee at the local Palestinian "shacks," conduct weekly political debates with soldiers, and try to pass the time in conversation. Therefore, it may have seemed trivial, for the activists, to share homemade cookies with the people they encounter

I would like to thank Shaul Setter, Annika Thiem, Yves Winter, Claire McKinney, and Jennifer Gaboury, all of whom read earlier drafts of this article and provided me with valuable suggestions. My thanks also to Gil Anidjar and to the anonymous reviewers at Politics \& Gender for their most constructive and productive feedback. I owe special thanks to Judith Butler, not only for reading an early draft and offering her precise and incisive comments but also for providing the conceptual infrastructure for this article, and to Merav Amir; our mutual work is the source of many of the ideas and thoughts herein.

Published by Cambridge University Press 1743-923X/1 130.00 for The Women and Politics Research Section of the American Political Science Association.

(C) The Women and Politics Research Section of the American Political Science Association, 2011 doi:10.1017/S1743923X11000353 
weekly. This is precisely what happened on that morning in 2004: a trivial event that probably happened many times before and many times afterwards.

Encouraged by positive reactions to the baked goods, this particular shift of women started bringing cookies to the checkpoint regularly. For various reasons (such as the spatial organization of the checkpoints, or the shared language and background) the soldiers became the main beneficiaries of this practice and, therefore, when it became known to other members of the organization, an internal debate was ignited among CPW activists: How could these women do such a thing? How will the Palestinians perceive us if we start giving treats to their oppressors? How can an oppositional organization tolerate its representatives acting like "mommies"? Some activists, however, voiced a different set of concerns: What if the cookies sweeten the way to the soldiers' hearts and eventually benefit the Palestinians? Happy soldiers tend to let people pass the checkpoint more easily; they tend to be less violent and more cooperative when the activists point to a specific problem. A fierce e-mail correspondence among CPW's members and intense discussions at the monthly meetings eventually ended with a decision: no more cookies at the checkpoint; no more overt maternal behavior. Yet, the fact that this debate had to be conducted, the fact that it was perceived as so significant, and the fact that every once in a while it surfaces again, reveal the significance of this (and similar) occurrence.

The story of the cookies is just one example of a wider claim, according to which activists of CPW often assume traditional gender roles - most often the maternal role - that enable them to increase the efficacy of their presence at the checkpoints. ${ }^{l}$ I analyze this mobilization of gender to show that the effectiveness of the maternal forms of intervention at the local level carry undesired effects at the structural level. These appropriations of gender roles facilitate a misreading of the watchers' action, which depoliticizes their critique and eventually incorporates it to justify the perpetuation - even entrenchment - of the checkpoints. I then move to consider a second case of Israeli women's activism: the case of Tali Fahima, a young Israeli woman who used her privileged body (privileged by the virtue of being both Jewish and female) as a human shield to protect a leader of a Palestinian military group. My query, however, remains similar: how does assuming particular gendered positions, or ascribing them to a political action,

1. On the receptivity of the Israeli public to a political opposition made from a maternal stance, see Neuman (2004) and Sharoni (1997). 
serve to marginalize or twist a political massage? Fahima was assumed to be this leader's lover, and this framing of her action, I argue, served to reinscribe national and racial anxieties in Israel.

Ultimately, by suggesting different readings of both cases, I show how the moment of co-optation - into both gender and national orders - opens new possibilities of resistance, or at least sets in motion new processes of resignification. The "full meaning" of any political story "can reveal itself only when it has ended," argued Arendt $(1998,192)$. But when does a political story end? And who is its legitimate teller? If these questions have no answers - and I propose that they rarely have - then the "full meaning" can never be determined, and I have no pretence of determining it here. My point is to raise different possible stories, which sometimes demand that we allow conflicting interpretations (even "judgments") to coexist.

\section{BACKGROUND}

In the midst of "peace negotiations," "peace processes," and "talks" of many kinds, Israel developed a system that enables it to maintain its control over the occupied Palestinian territories with minimal physical (military) presence and direct violence. At stake is Israel's ability to present (and perceive) itself as being peace seeking without relinquishing the benefits of controlling the land and its resources. Halper (2000) has termed this system "the matrix of control":

It is an interlocking series of mechanisms, only a few of which require physical occupation of territory, that allow Israel to control every aspect of Palestinian life in the Occupied Territories. The matrix works like the Japanese game of Go. Instead of defeating your opponent as in chess, in Go you win by immobilizing your opponent, by gaining control of key points of a matrix so that every time s/he moves s/he encounters an obstacle of some kind.

Writing in 2000, Halper could have seen only the seeds of the dense grid of checkpoints that would become the predominant component within this matrix. Together with a convoluted and opaque system of permits, two separate systems of roads, the separation barrier, and hundreds of dirt mounds, rock piles, fences, and gates, the manned checkpoints strictly regulate Palestinian movement and with it Palestinian lives.

As a report by B'Tselem, an Israeli human rights organization, states: "Since the early 1990s, Israel has gradually and steadily expanded and 
refined its movement restrictions policy," and by 2001 these restrictions became "unprecedented"; "Palestinian freedom of movement has turned from a fundamental human right to a privilege that Israel grants or withholds as it deems fit" (B'Tselem 2007, 7-8). In the summer of 2010, there were 64 manned checkpoints (47 of them in the midst of the Palestinian territories - surrounding the big cities and dissecting roads; the rest were closer to the Green Line, marking an "entry point" to Israel) and 540 physical obstacles in the West Bank (OCHA 2010). The density and dispersal of the checkpoints mean that they prevent - or at least severely hinder - what many of us see as mundane, daily life: going to work, attending a relative's wedding, shopping at the market, or going to school. All are simple routines for most people, but they are denied to most Palestinians or are "purchased" with the cost of valuable time; time that is robbed, as Hass (2005) put it, and "cannot ever be returned":

The loss of time, which Israel is stealing every day from 3.5 million people, is evident everywhere: in the damage it causes to their ability to earn a living; in their economic, family and cultural activity; in the leisure hours, in studies and in creativity; and in the shrinking of the space in which every individual lives and therefore the narrowing of their horizon and their expectations.

In other words, "scarcity of time disables space" (Handel 2009). It narrows the land and disables the possibility of forming a political community. What thus emerges is a mode of controlling the space and the population that inhabits it by controlling the temporality and continuity of the movement within it. ${ }^{2}$

\section{TREACHEROUS PLAYGROUNDS: CPW}

In 2001, as the checkpoints expanded, a small group of Israeli women established CPW to oppose the checkpoints as one of the occupation's

2. Control over movement enables Israel to maintain two of the key distinctions underlying the occupation. The distinction between space and population (Gordon 2008) is maintained when the fragmentation of space renders vast areas effectively inaccessible to the majority of a (fragmented) Palestinian population. As Handel shows, the construction of different moving bodies - of Jewish settlers and soldiers on the one hand, and of Palestinians on the other - and the radical differentiations between the regulations to which the movements of these bodies are subjected enforce the separation between the two major populations under Israeli rule: citizens and noncitizens (Azoulay and Ophir 2008). For more on the regime of movement in the occupied Palestinian territories, see Bishara (2006) and Weizman (2007). 
primary apparatuses. ${ }^{3}$ Whereas the main practice of the organization is observation and documentation, sometimes activists cannot maintain this detached position. Some experience an urge to intervene in some form to somehow - marginally as it may be - reduce the hardship inflicted upon Palestinians by and at the checkpoints. Indeed, the social and spatial layouts of the checkpoints facilitate forms of intervention. At many checkpoints, activists often stand adjacent to the soldiers, they share language and nationality, and they often belong to the economic and ethnic elite in Israel, which grants them some informal authority. Thus, different practices of intervention are common within the organization. Sometimes these interventions take a discrete form (such as standing next to a Palestinian to protect her from violent eruptions by soldiers); in other cases, the organization is involved in more systemic negotiations with the army (such as appeals to regional commanders in order to change checkpoint regulations).

Such interventions are not part of the agreed ideology or forms of operation of the organization, and in recent years, the organization has become increasingly critical of them. At times, however, such forms of intervention - in the singular, concrete, and immediate benefit they may hold seem the most urgent. This sense of urgency produces an almostimpossible-to-resist desire to be effective. This, in turn, prompts conformist gender practices aimed at producing a traditional voice to which the soldier can relate. The performance of such familiar forms of relationships often makes the soldiers more susceptible to the activists' requests requests to release people who have been detained as a form of punishment, to allow an ill person hospital access even if he or she does not have the necessary permits, or to open another line when the lines are getting long and the sun is setting. One of these familiar positions is the maternal, which is relatively available to most activists also because most soldiers are between the ages of 18 and 21 , and most activists are at least in their 50s. Many are indeed mothers and grandmothers of soldiers.

The all-female makeup of CPW produces ambivalent, and at times contradictory, rationales. Since I have elaborated on this subject elsewhere (Kotef and Amir 2007), it is sufficient to argue that it translates neither into an articulated feminist politics of the organization nor into an explicit or coherent form of maternal politics. "Maternalism," rather,

3. I joined the organization in 2004 and was an active member for two years until I left Israel. This article is based on my experience during these years and supported by further unsystematic engagements I had with the organization during my visits to Israel and online. 
appears on isolated occasions and amounts to sporadic employment of maternal practices by individual activists. At the checkpoints, these practices may include speaking to soldiers with a particular intonation, expressing concern to the soldiers themselves, "educating" them, demanding that they "behave better," or bringing them cookies.

We can argue, then, that we have here a strategic appropriation of the maternal position that should be differentiated from two main positions: first, from the position of women's peace organizations that see in their members' social roles as mothers an essential aspect of their all-female makeup and that base their antiwar politics on maternal language and practices (Ruddick 1995); ${ }^{4}$ and second, from the position of women's peace organizations that adopt gender essentialism as an overall strategy and rely on essentialist assumptions to position themselves in a specific (non) political niche - mostly humanitarian - that enables them to operate (Helms 2007; Neuman 2004). Unlike these two options, in the case of CPW the motherly stance is not integral to the operation of the organization. It does not serve as the organization's source of legitimacy and does not form the grounds on which the activists declare their activities. Rather, it is mobilized locally and ad hoc as a tool assisting the activists to act when they can no longer simply watch.

Sparks's (1997) notion of "strategic straightness" may be helpful in further explaining such mobilizations of gender. In the particular context of their political intervention, CPW activists may be seen as situated on the verge of what Sparks terms dissident citizenship: "the practices of marginalized citizens, who publicly contest prevailing arrangements of power by means of oppositional democratic practices that augment or replace institutionalized channels of democratic opposition when those channels are inadequate or unavailable" (Sparks 1997, 75). As upper- to middle-class Ashkenazi (Jews of European heritage), CPW activists are by no means "marginalized citizens." Yet since the view that the checkpoints are necessary to prevent the massacre of Israelis is so prevalent in Israel today, their call to dismantle the checkpoints renders their political voice precarious; they are often accused of being traitors or dismissed as madwomen. When such precariousness is at play, argues Sparks, organizations may adopt "strategic straightness:" an alignment to heteronormative positions in order to perform from a position of respectability and

4. In Israel, the most dominant among such organizations was Four Mothers, which operated against the occupation of Lebanon. Tronto's (2008) work on peacekeeping intervention suggests that such a stance is - or should be - inherent to the praxis of peace promotion and peacekeeping. 
belonging to a social center. Such performances create a base of legitimacy that supports controversial political claims (Sparks 2009). Adopting a maternal stance may be understood precisely within this framework. ${ }^{5}$

It seems that behind this explanation lies the assumption that the maternal stance functions here not (only) as part of one's identity but also as something of a "strategy": playing on gender and gender stereotypes not in order to "be" a person gendered in a particular way but, rather, in order to charge one's actions with more potency. Yet recent feminist and queer scholarship has called into question this differentiation between "being" and "doing." If gender is produced through performing gender stances and gendered practices, as Butler (1999) has argued, then one is always on the verge of becoming what one mobilizes. Moreover, one can successfully mobilize only what is already available as plausible within the array of gender identities. This point is not new, but here it has further stakes: It means that a "strategy" can never be fully controlled by the activist. The possibility of adopting it ad hoc, of using it one moment for one purpose and then abandoning it, is not always an option. A strategy can become part of one's "identity" it can be called upon, summoned, taken to be permanent, and become the lens through which one's actions are interpreted.

This claim can be seen as introducing a Butlerian inversion into Arendt's theory of action by examining the manners by which political actions appear on a discursive public surface. ${ }^{6}$ While what follows is, to some extent, a concrete manifestation of Arendt's argument regarding the "inherent unpredictability" of political actions, it also shows that her claim that the essence of the actor emerges through the action does not carry the promise of authenticity and uniqueness she attaches to it. Rather, the emerging "essence" - that "lasting state of being which is neither subject to change nor capable of effecting change" (Arendt, 1998) - is in this case precisely the object of many poststructuralist feminist critiques. It is an "identity" that can never achieve its pretence of stability nor the presumed authenticity it seemingly marks. It is but an assemblage of "whatnesses" - of possible social positions one can occupy (or not) in different ways. The "who" that emerges here is not a manifestation of the actors' uniqueness, but a cliché to which they "fold

5. Swerdlow (1993) describes similar practices of American peace activists who deployed maternal language to gain credibility and perform loyalty (if not patriotism) as they faced charges of subversion during the Cold War.

6. See Honig (1995) for a more systematic account of the theoretical grounds that enable one to examine Arendt's political theory through the lens of Butler's notion of performativity. 
over" by an action they may have imagined as detachable from their identity. (To put it more concretely: CPW activists do not necessarily perceive themselves as mothers in this context and may not be mothers at all).

Consider a section from a CPW report that manifests this collapse:

At the beginning she cried with no voice; only big tears ran down her scared face; scared as any face of any child who suddenly lost her mom. We approached her: "Where is your mother? Are you lost"? . . . We approached the soldier; perhaps he can call the mother through the loudspeaker system. This [only] made him laugh. . . The crying of the girl got louder and louder. I tried to caress her when my cell phone rang. My older son called to tell me that my ll-year-old daughter missed her drama class again because I forgot to call and remind him to take her to the community center. "Why are the Palestinians more important to you than your own children?" he rebuked me. I heard my daughter crying at the other end of the line as I suddenly saw the mother. . . The girl ran to her mother, held strongly to her brother's hand and they all left the checkpoint. $^{7}$

The activist now becomes a mother, and her motherhood becomes the pivot around which everything that happens at the checkpoint is organized, the lens through which suffering and wrongdoing, as well as the activist's own position, are perceived and reported. But it is quite unclear what this "becoming" means in this context. What, for example, do such performances of motherhood at the front line do to the meaning of motherhood itself? To the identity of the women of CPW - as both activists and mothers? To the addressees of their maternal concerns (and who are these addressees? - soldiers? Palestinians? both? - and what would this "both" produce at the level of national and racial identities?)? I touch upon some of these questions in the last section of this paper, but I think that there is an altogether different set of questions that should be prioritized in this case. The effects of playing with gender identities here may have a bearing not only on the identity of the actors but also on the materiality of the occupation itself.

In the summer of 2007, at the Beit Furick checkpoint, a shift of watchers met an officer they had previously encountered. They wrote in their report:

The officer asks that we wait. In a few minutes he will be available and he wants to tell us something that will interest us for sure. We waited and he told us that he is working on improving the way children are treated at the

7. CPW internal report, October 4, 2006 (my translation). 
checkpoint. He wants to have a separate line for children, with a more considerate approach. In addition, he intends to build a small playground at the checkpoint, in which they could wait until their parents will get through the adult lines. ${ }^{8}$

You may be able to hear in these words the pride the officer took in telling the activists about his new plan, as if he had responded to their demand a demand that was never made but perhaps surfaced, despite the activists, as an outcome of their collapse into motherhood. A playground, after all, speaks precisely to the concerns of "the mother."

A maternal presence at the checkpoints can prompt a (mis)reading of CPW's critique as rationalized mainly by care and concern for humanitarian aspects. This critique is thereby depoliticized and reconfigured as a critique that can be addressed by improving the facilities at the checkpoints instead of dismantling them: by erecting roofs, constructing toilet facilities, bringing water tanks, manufacturing "humanitarian gates" for people in wheelchairs, or even building playgrounds. The playground - which as of yet has not been built is thus just one instance of a broader process in which the checkpoints have evolved into elaborate monstrosities that masquerade as "humane" facilities. ${ }^{9}$ At a site whose mere existence is a violation of human rights and human dignity, a playground offers the pretense of displaying a humane approach, as if parents would be relieved if their children played under the drawn weapons of Israeli soldiers while they are squeezed together in the long lines; as if a slide or a swing would make people blind to the wrongs of the checkpoints.

At stake in this expansion of the checkpoints is more than grabbing Palestinian land to build a grotesque structure, more than a redundant facility of the occupying forces in the midst of an occupied land. Since many checkpoints have also attained the façade of normal border crossings, they conceal not merely concrete violence but also occupation. At stake, therefore, is the possibility of justifying and maintaining a more pervasive occupation simultaneously with an ongoing "peace process." This development is far from being the contribution of CPW alone. Moreover, within the operation of the organization, it may be ascribed to the wider instinctive interventions aimed at resolving local problems and not to their "maternal moments." Without understanding the concrete materialization of this instinct

8. Checkpoint Watch Report, May 4, 2007 (my translation).

9. While this specific playground was never built, another was built in Barta'a (Reihan) checkpoint. 
within maternal positions, however, we cannot fully understand the smooth slide by which a political critique of the Israeli occupation is framed as a humanitarian critique that is eventually essential to the occupation's maintenance. ${ }^{10}$

\section{OVER THE EDGE OF POLITICS: TALI FAHIMA}

In August 2003, Tali Fahima, a young Jewish Israeli who was never part of a formal political organization, traveled for the first time to the Palestinian city of Jenin in order to meet with Zacharia Zubeidi. Zubeidi was the head of the Al-Aqsa Martyrs Brigade, a Palestinian military group that planned and executed several suicide attacks in Israel and, until recently, was known for its persistent refusal of any form of cease-fire with Israel. Although Israelis are prohibited from entering Palestinian cities, Fahima visited Jenin several times and was arrested and released several times as she crossed the checkpoints surrounding this city. After Zubeidi escaped a targeted assassination attempt, Fahima publicly declared that she would serve as his human shield and moved to his house to live with him and his family, arousing a turbulent reaction in Israel. This time, on her way back from Jenin, she was arrested, jailed, and accused of treason and assisting an enemy in a time of war. ${ }^{11}$

Yet, although these were the formal charges, they concealed another allegation that was perceived to be at least as severe. Despite her denials, Fahima was "accused" of being Zubeidi's lover, and the alleged affair between the two was the focus of almost all media coverage of her story. The formal charges of "betrayal" of the homeland thus rested on another assumed betrayal, a sexual betrayal of the only legitimate sexual partner: Jewish, Israeli, man. And the fact that Fahima was often described at the same time as having a "lesbian look" suggests that the precise practice by which she transgressed this prescribed sexual norm was not important.

10. On this symbiosis, see Azoulay and Ophir 2004; Kotef and Amir 2007; Weizman 2007.

11. The charges were very soon radically reduced, eventually amounting to the claim that Fahima had translated a military map for Zubeidi. Fahima was found guilty (even though Zubeidi speaks fluent Hebrew and it is doubtful that he needed Fahima's translation services) and sent to prison. She was released after more than two years in jail. The link between passing information to a rival ethnic/ national group and engaging in (forbidden) sexual ties with members of this group was not invented in Israel. Maunaguru cites a letter published in the LTTE (The Liberation Tigers of Tamil Eelam) official newspaper Eelanatham in 1991. The letter states that young Tamil women traveling to Colombo "become friendly with policemen from Sinhala and Muslim communities and lose their morals. In addition, they pass on information on the struggle which is taking place in the north" (2009, 169-70). 
"Lesbian," "whore," or "slut," Fahima was, above all, blamed for having a perverted sexual orientation: She prefers to have sex with "Arabs." It was as if the strength of the sexual prohibition was recruited to reinforce the rationale of apartheid, to charge its transgression with the potency only sexual taboos can convey. The assumed link drawn between women's sexual behavior and the integrity of national borders has been widely researched. At a certain level, Fahima's case is yet another example of this familiar phenomenon. What is interesting here, however, is that the appeal to sexuality became almost the precondition for uttering any claim within this story, including, eventually, in the versions told by Fahima herself. She accused her interrogators of sexual harassment, trying to question their credibility using the same language they used in discrediting her. Later, she called Zubeidi "the whore of the Shin Bet" (Israel's Security Services) after he had reached an agreement with the Israeli General Security Services and surrendered his weapons ("Tali Fahima" 2008).

Nevertheless, perhaps knowing that sexual taboos are more forceful when superimposed on national and racial borderlines, Fahima tried to counter the accusations of national/sexual transgression using a different technique. She tried to distill from her action a pure political message and to cleanse from it everything that is personal. Not only did she refuse to talk about her personal life in interviews, but she also constantly declared that she had none. When the alleged affair was mentioned, she often replied along the lines of this response:

You should understand, in Jenin there is neither time nor space for fun, for going out; there is neither space nor time for life. When you are in Jenin you don't think of love. Jenin wallows in poverty, in survival, in war, in struggle. When you are there you cannot but think of death. . . In Jenin love is a luxury. Who has the time for love? (Levi 2007)

Jenin appears here as a site with no life, let alone "personal life," with their connotations of leisure or love. It is a city of death. Fahima literally became her political cause and her body became the materialization of that cause: either as a buffer between Israeli bombs and Zubeidi or as an incarnation of what may be called "peace" - the coexistence of Israel and Palestine (represented here by herself and Zubeidi).

In the following section, I propose a different way of reading Fahima's action: one that does not lend itself to such a separation of the personal and the political. Perhaps Fahima's choice to account for her actions as if she were a purely political subject attests to her inability to see that her 
own action refuses the language by which these distinctions are made. But perhaps she had strategic reasons to hold to these distinctions. Perhaps she realized that if she appears as a woman, as a sexual, desiring being, then she risks a certain political credibility. Sjoberg and Gentry (2006) describe precisely such a dynamic: ascribing sexual motives to women's political actions serves to "personalize" these actions and depoliticize them. ${ }^{12}$

This depoliticization, as Hasso (2005) shows, effaces the message of the activists themselves (in her case, suicide bombers/martyrs), thereby rendering it susceptible to others' interpretations. Indeed, once it became all about love - or perhaps all about sex - Fahima's action was not merely distorted to the degree that its political meaning was almost completely drained out; her message was also turned against itself. In one of her investigations, her interrogator brought her a gift. "I thought this is chocolate and unwrapped it," she recalled. But it was a pregnancy test: "He asked whether I intend to call my child Muhammad and whether he will be a little terrorist. "Why a little terrorist?" Fahima eventually caved in to this excessive and invasive overinterpretation of the motivations of her act, asserting, "He will be a big one" (Levi 2007).

We could probably spend an entire paper analyzing this claim. We could, for example, point to a paradox embedded in it: At the very moment in which this claim defeats the regime of separation, it also accepts its fundamental assumptions: the identification of all Palestinians with terrorists and of the very "mixing" of Palestinians and Jews as a threat. The pregnancy, which may be seen as the ultimate moment of coexistence, also becomes the moment of destruction and violence. Or we could take it to show that love must be integrated into our explanations for national struggles, including the violence they often employ. The fictive maternal love of Fahima to her fictive fetus brings to the surface real loves of people to their land and to their children who live under occupation or are killed because of it. ${ }^{13}$ But For now, I want to take from this claim only one point. Living in Jenin, with the Al-Aqsa Martyrs Brigade, with Zubeidi, Tali Fahima tried to

12. Accordingly, it is not uncommon that women who identify with suffering alongside "wrong" national lines are called "traitors, sluts, lesbians, and whores" (Cornell 2004, 322).

13. As Stoler's work clearly shows, love and desire are integral to colonial structures, including colonial violence. Love can thus appear not as a category working to personalize and depoliticize, as suggested here, as well as by Hasso (2005) or Sjoberg and Gentry (2006). Love, in other words, can be political. (Haq's (2008) work on the militarization of motherhood within the LT (Lashkar-i-Taiba) struggle in Pakistan provides here another fascinating example, that (re)contextualizes this relation of love and nationalist violence (almost parallel to the story of Fahima) within the context of motherhood.) Perhaps, moreover, we should resist these distinctions from the outset, following works such as Povinelli's (2006) or Butler's (2000), which undermine, at least to some extent, the very terms from which this debate is conducted. 
demonstrate that not all Palestinians, not even all Palestinian fighters, aspire to kill Israelis. But through the alleged sexual relations, her body was taken to prove that they all aspire to eradicate Israel as a Jewish state. Her fictively pregnant body came to encapsulate within it a combination of the threats that the Palestinians pose to Israelis: a demographic threat, the threat of terror, the unwanted penetration to the borders of Israel, and the related, all-too-familiar fear of the (presumably excessive) sexuality of the racialized other. ${ }^{14}$

\section{THE PARADOXES OF SUCCESSFUL FAILURES: ANOTHER POSSIBLE READING}

I have presented two different cases of women's left-wing activism and the ways gender "intersects" with their political action. In both, a position within a traditional gender stance molds a political action into traditionally nonpolitical patterns and thereby turns the action against itself. In the case of CPW, traditional gender positions are adopted as a tool assisting the activists when they feel it is urgent to be effective. Yet these positions take over the presence of the activists at the checkpoints. Their effects surpass the intention that drew their mobilization; they are interpellated by the army, facilitating a process of co-optation, and become building blocks for the checkpoints. In Fahima's case, a different traditional position of women (that of the lover) is read into the political action by its critics, in an attempt to delegitimize it. This ascription renders a political action less effective (rather than facilitating the deleterious effects of such action).

Neither of these cases is one of unequivocally feminism-based activism, and neither explicitly relies on agreed-upon assumptions regarding the gendered positions of the activists. To the contrary, in both cases the activists attempt to sideline the fact that they are women and foreground a leftist, antioccupation political action. This divide, which may be limited to the surface of declared rationales and should perhaps be exposed as fictive, highlights a significant facet in the operation of gender: Both cases enable us to see the extent to which our gendered and sexual positions are given to others and remind us that we must account for the effects of this "giveness" on our political action.

14. The relation between these last two is important. If the coherence of the state is based on a sexual contract, as Pateman (1988) argues, and if this contract is crucial in understanding current regimes of violence, as Das (2008) suggests, then we must bear in mind that this contract was always also a racial contract. 
These two stories are much more ambivalent than what I have allowed, however. First, they cannot simply be told as stories of "failure." CPW succeeded in completely altering the public debate concerning the checkpoints in Israel and outside of it. It continues to reduce violence, harassment, and misconduct at the checkpoints on a daily basis. And if a certain degree of cooptation is what enables one person - and sometimes 200 people - to get home earlier, or enables a sick person to get needed treatments, then it cannot be a failure here. Furthermore, the story of CPW cannot be understood merely as a mobilization of conservative gendered identities to promote or to counter some radical left politics that either fails or succeeds, or both. Beyond the ambivalence of the failure/ success criterion, it is also not altogether clear what happens to the categories of gender in this mobilization. Many women's organizations have drawn on the maternal positions of their members to radicalize motherhood (or their members), to politicize it, or better, to reveal that the political versus private/domestic division can never be maintained (Guzman Bouvard 2002; Neugebauer 1998; Orleck 1997). Eventually, organizations that rely on maternal positions as part of their political action "cannot be viewed as either reinforcing or tearing down gender power relations. They do both" (Bayard de Volo 2006, 162). We can return here to Butler's notion of performativity to state that any duplication of a traditional gender stance, any repetition through which this stance is assumed, is always also the means for its destabilization.

While CPW does not explicitly seek to radicalize motherhood or change gender hierarchies, its members' maternal presence at the new front line can be viewed as doing so. More importantly, it is this very presence that may have the potential of subverting the racial assumptions underlying the relations between Israeli Jews and Palestinians. If we examine the maternal practices of CPW activists in relation to national - and colonial - assumptions in which configurations of motherhood are often given (de Alwis 2002; Stoler 1995), then we can find in them traces of a critique, not simply of concrete checkpoints and a regime of occupation but also of the ideology of separation that has founded both the Zionist and the Palestinian national projects at least since 1948.

At this point we can return to the cookies. In the story with which I opened, cookies were brought to the checkpoint as part of a strategic or instinctive adoption of a maternal stance. But more often, cookies are present at the checkpoints in their absence: They are the subject of a common accusation hurled by the soldiers at CPW members: "Why do you neglect to bring us cookies or soft drinks?" "Why are you such bad mothers?" "Why, in the 
words of the activists's child from the report I cited earlier,' are the Palestinians more important to you than your own children?" A "collapse into motherhood" - an uninvited summoning of the maternal position into the activists' presence at the checkpoint - fails here on its own terms. The activists appear to be quite bad mothers, and it is this very failure that has the potential to disrupt something in the social, racial, and national fabric underlying the occupation. As the main object of their motherly care resides outside the "Jewish Israeli family," we may see here the emergence of the possibility of a new "family" (Mansbach 2007).

Nevertheless, it is important to note in this context that "disruption" must not be celebrated for its own sake. After all, even for Palestinians, the women of CPW are quite bad mothers: They abandon them daily and often can only watch their distress without doing much. More importantly, the very notions of "help," "care," and "maternal concern" are highly problematic in this context. They reinforce one of the key racial/national hierarchies at the base of the occupation: the assumption that the Palestinians are childlike and unable to take care of themselves. ${ }^{15}$

Like being a bad mother in the case of CPW activists, "having sex" with the "wrong" person can be read as an act pushing against accepted social borders and disrupting social barriers. We have here the same pattern identified by Cornell in practices of public mourning for "the enemy": Something that is often seen as a private sentiment emerges as a political practice as it disrupts, at one and the same time, both the deployment of women as representing the nation and the order of "nationalist aggression" (2004, 321). ${ }^{16}$ With this disruption and its potential for reshaping identities and affiliations, maternal care or love/friendship can become political practices (even if they are not inherently so).

Setter suggested that the case of Fahima can be told as a story of a dual resistance becoming a single one: a "political" resistance to the Israeli project of separation and a "personal" resistance to identity categories, which are merged in the desiring body of Fahima: "Every step she made in her way to Jenin marks another break in identity, along the course of a self-transforming desire," he argues. "She first stopped watching Israeli news and exposed herself to Arabic media; she then made long phone calls to her new Palestinian friends; then she talked to a terrorist,

15. On the crucial role of this assumption in justifying the current Israeli occupation, see Kotef and Amir, 2011.

16. Butler (2004) probably made the clearest case for this political bearing of mourning. 
and then consented to his invitation to his homeland, his town, his house; then she stayed there, in his house, with his family" (Setter 2007, 3).

Indeed, since 2003, Fahima has radically reshaped her identity. She left Tel Aviv and moved to the Israeli Palestinian town of Ar'ara (located within the 1948 borders). She slowly started identifying herself with the Palestinians: "We are still living under an occupation," she told a reporter in an interview from 2008 ("Tali Fahima" 2008). After a couple of years, she also converted to Islam. ${ }^{17}$ This change can be understood as part of a story of a woman who lost her social and economic networks, was forced out of her job, her apartment, and her circle of friends due to her political actions, and is desperately trying to find others. Indeed, most accounts of her story in the Israeli media present a woman who lost her sanity in the process.

Yet we can take this to be a story about a mode of action that calls into question almost everything assumed as a given within the Jewish Israeli identity and that challenges a lot of what goes uncontested in the internal and foreign politics of Israel. From the moment Fahima became a political player, her talk about illegality and injustice was so radical that it was pushed over the edge of what is marked as (liberal) politics: thrust into the sexual domain and later situated by Fahima herself within the religious domain. But her action from within these two domains can also be understood as a break from Israeli society, Israeli politics, and a Jewish Israeli identity.

Becoming a Palestinian, being the lover of a Palestinian, or simply being a friend of a Palestinian, Fahima changed the demarcation of the "we," which is arguably the most radical political act. In her mode of action, she also challenged the demarcation of political action, specifically the possibility of separating the personal and the political. Her body itself as a site of movement, desire, dwelling, and ethnic and racist demarcations - became a site of resistance. Moving back and forth between Tel Aviv and Jenin challenged the regime of separation between Palestinians and Israelis. Maintaining a close proximity to "the enemy," her body challenged the presupposition that such a proximity always results in death. As a leftist activist from a low-income family and of a North African origin, Fahima also entered a political arena usually

17. This may echo the story of another Israeli leftist activist - of a North African decent like herself whose primary political action, like hers, was not done on behalf of an organization; who also spent years in an Israeli prison after being accused of treason; and who, like her, converted to another religion Mordechai Vanunu. Working through these lines of similarities is beyond the scope of this article, but can probably shed some light on the aforementioned processes and their significance. 
inhabited by upper-middle-class Ashkenazis. Finally, when she replaced Tel Aviv with Ar'ara, Fahima replaced 1967 with 1948; that is, she replaced the struggle against the occupation, against targeted assassinations, and military bombing (or checkpoints, for that matter) with a struggle about the nature of the Israeli/Palestinian society.

\section{CONCLUSION}

My analysis brings together two, usually distinct, fields and tries to rethink both. First, I show that we have to take gender into account when trying to understand the unintended, uncalculated effects of political actions that are sometimes imagined to be taking place outside the realm of gender (in this case, an antioccupation agenda). The critique of humanitarian interventions and human rights discourse often fails to consider gender altogether (De Waal 1997; Foley 2009; Ophir 2003). Or it considers the gender of victims - of the addressees of the political action (as in the work of Bohmer and Shuman [2008] on refugees). I contend that this critique should also be attentive to the gendered positions of activists.

Second, my analysis departs from some of the shared assumptions underlying the feminist debate regarding different deployments of gender in women's political activism. The most significant among these assumptions are 1) viewing the deployment of gender as part of an intentional ideology, 2) portraying this ideology as either strategic or part of an essentialist identity claim, and 3) emphasizing the question of whether this is beneficial or precarious to women (or at least to gender hierarchies in a given society) (see, e.g., Helms, 2003; Molyneux 1985; Neugebauer 1998; Samuel 2003). Instead, I wish to set aside the notion of intention and challenge the assumed dichotomy between strategy and essentialist presupposition about identity. More importantly, I seek to understand how particular performances of gender are appropriated by, interpellated by, and work with the mechanisms of the occupation.

This analysis also offers some reflections on the nature of political action and, hence, takes part in a dialogue with Arendt. Arendt's account of the connections among territorial residence, sovereignty, and rights, as well as her vision of unbinding the tie between national sovereignty and human rights within an Arab-Israeli confederation, are undoubtedly relevant when considering the Israeli-Palestinian conflict. Focusing on activism, however, I limit my engagement here with Arendt to her theory 
of action. Action, she argues, has its own life. Since, by definition, it materializes and is carried through in conditions of plurality (in a political space), it can never be reduced to the actor's intentions and is inherently unpredictable. But beyond a manifestation of this claim, the two cases here show that Arendt's narrow understanding of political action - which would have necessarily missed the political facets I delineated in the previous section - renders her blind to the extent to which the conditions of plurality also undermine the one trace of an ontology of individualism with which she cannot dispense: the figure of the fantasmatic hero. ${ }^{18}$ This critique does not propose that agency itself is a fiction, but rather that we have to take into account the manners by which agency is always given to others as well.

How can one effectively act if the effects of one's political action can always be co-opted into the powers they seek to oppose, if one's political voice can always be overturned, resignified, and taken to mean the opposite? Perhaps all we can do to work within this co-optation is examine the local practices and effects resulting from different appropriations of gender positions, unfold the various meanings they may contain, lay bare the multiple manners by which they are read, and hope that we reproduce less of what we want to put an end to and more of what we want to establish or sustain. Either way, we can follow Arendt's call and say that despite the frailty and risks that political action inherently carries, we should not abandon it.

In the summer of 2010, a small group of CPW activists smuggled several Palestinian women and their children across the checkpoint and took them to see the sea, Tel Aviv, and Jerusalem. They broke the law and, in an ad they published in Israeli newspapers, called others to follow them on a campaign of civil disobedience:

We do not recognize the legality of the "Law of Entry into Israel," a law allowing any Israeli and any Jew to travel freely in all parts of the land, but denying the same right to Palestinians - despite the fact that this is their country too. This law robs them of the right to visit towns and villages across the Green Line - places with which they have deeply rooted

18. Feminist scholars have elaborately argued against Arendt's narrow demarcation of the political sphere, which excludes from the domain of politics many of the power relations, hierarchies, and institutions feminists have endeavored to politicize. Benhabib (1993), and Dietz (2002) suggest that beyond this obvious problem, Arendt is nonetheless valuable to feminist politics/theory. But as Zerilli suggests, "Notwithstanding a recent shift in feminist attitudes towards Arendt . . . what stubbornly remains at the end of the day is her apparent refusal to include social issues among the concerns of politics $(2005,3)$. Zerilli, as well as Honig (1995), propose a slightly more inclusive reading of Arendt's notion of "the social," yet an interpretative effort is still required to allow inclusion of such issues in the Arendtian sphere of "the political." 
family, heritage and national connections. Therefore, we obeyed the voice of our conscience and took the liberty of bringing these women to a few of these places. They and we have taken the risk together, with clear minds and strong conviction. Thus, we Israelis have earned another great privilege: to experience in our nation, a nation living on its sword, one of the most beautiful and emotional days of our life; to get to know brave Palestinian women, full of the joy of life, to spend time with them and to be free with them - even if only for a single day. (Hammerman et al. 2010)

In the ad, these women situate themselves as followers of Rosa Parks and Martin Luther King, Jr., but they also follow Fahima. Like her, they challenge the quintessential logic of the occupation and the logic of separation. ${ }^{19}$ In their acts, these women resisted not merely a particular law (the "Law of Entry into Israel"), but also an entire order deemed illegal and unjust.

Refusing is a political act in and of itself: refusing to play a game in which one is bound to lose; refusing to obey an order of radical injustice and the laws governing it; or, as in Fahima's case, refusing to be part of a certain collective. This refusal is not merely the result of personal judgment, as Arendt argues, or a retreat from the political that is the condition to "go on living with [oneself]" in a regime whose law has become unlawful $(2003,44)$. As Arendt herself suggests, in a political context, obedience is an act of supporting the government and its rule. A refusal to partake in the political order is, therefore, an act of interruption, of tearing holes in the political fabric and revealing the very unlawfulness of the law. It can be the most effective (or at least the most responsible) political action.

Hagar Kotef is Post Doctoral Fellow at Columbia University, New York, NY: hk2544@columbia.edu

\section{REFERENCES}

Arendt, Hannah. 1998. The Human Condition. Chicago: The University of Chicago Press. 2003. Responsibility and Judgment. Ed. Jerome Kohn. New York: Schocken Books Azoulay, Ariella, and Adi Ophir. 2004. "The Ruling Apparatus of Control in the Occupied Territories." Presented at The Politics of Humanitarianism in the Occupied Palestinian Territories conference, Van Leer Jerusalem Institute.

19. The Israeli occupation is a set of separations: between two different geographical zones, between citizens and non-citizens, between people and territories, between two (and actually more) legal systems, and between different vertical layers of the space. 
2008. This Regime Which Is Not One: Occupation and Democracy between the Sea and the River (from 1967 Onwards). Tel Aviv: Resling (in Hebrew).

Bayard de Volo, Lorrain. 2006. "The Dynamics of Emotion and Activism: Grief, Gender, and Collective Identity in Revolutionary Nicaragua," Mobilization 11 (3): 149-67.

Benhabib, Seyla. 1993. "Feminist Theory and Hannah Arendt's Concept of Public Space." History of the Human Sciences 6 (2): 97-114.

Bishara, Azmi. 2006. Yearning in the Land of Checkpoints. Tel Aviv: Babel (in Hebrew).

Bohmer, Carol, and Amy Shuman. 2008. Rejecting Refugees: Political Asylum in the 21st Century. New York: Routledge.

B'Tselem. 2007. "Ground to a Halt: Denial of Palestinian's Freedom of Movement in the West Bank.” http://www.btselem.org/Download/200708_Ground_to_a_Halt_Eng.pdf.

Butler, Judith. 1999. Gender Trouble: Feminism and the Subversion of Identity. New York: Routledge.

- 2000. Antigone's Claim. New York: Columbia University Press.

- 2004. Precarious Life: The Powers of Mourning and Violence. London: Verso.

Cornell, Drucilla. 2004. "The New Political Infamy and the Sacrilege of Feminism." Metaphilosophy 35 (3): 313-29.

Das, Veena. 2008. "Violence, Gender, and Subjectivity." Annual Review of Anthropology 37: 283-99.

De Alwis, Malathi. 2002. “'Housewives of the Public': The Cultural Signification of the Sri Lankan Nation.” In Crossing Borders \& Shifting Boundaries, vol.2, ed. Ilse Lenz et al. Opladen: Leske + Budrich, 19-38.

De Waal, Alex. 1997. Famine Crimes: Politics and the Disaster Relief Industry in Africa. Bloomington: Indiana University Press.

Dietz, Mary. 2002. Turning Operations: Feminism, Arendt and Politics. New York: Routledge.

Gordon, Neve. 2008. Israel's Occupation. Berkeley: University of California Press.

Guzman Bouvard, Marguerite. 2002. Revolutionizing Motherhood. Oxford: SR Books.

Foley, Conor. 2009. The Thin Blue Line: How Humanitarianism Went to War. New York: Verso.

Halper, Jeff. 2000. “The 94 Percent Solution: The Matrix of Control.” Middle East Report 216. http://www.merip.org/mer/mer216/94-percent-solution (accessed September 2011)

Hammerman, Ilana et al. 2010. "We Do Not Obey." http://www.kibush.co.il/show_file. asp?num=41562 (last accessed September 27, 2010).

Handel, Ariel. 2009. "Where, Where to and When in the Occupied Palestinian Territories: An Introduction to a Geography of Disaster." In The Power of Inclusive Exclusion, ed. Adi Ophir, Michal Givoni, and Sari Hanafi. New York: Zone Books, 179-222.

Haq, Farhat. 2008. "Militarism and Motherhood: The Women of the Lashkar-i-Tayyabia in Pakistan." In War and Terror: Feminist Perspectives, ed. Karen Alexander and Mary E. Hawkesworth. Chicago: University of Chicago Press.

Hass, Amira. 2005. “The Natives' Time Is Cheap.” Ha'aretz. February 23.

Hasso, Frances. 2005. "Discursive and Political Deployments by/of the 2002 Palestinian Women Suicide Bombers/Martyrs." Feminist Review 81: 23-51.

Helms, Elissa. 2003 "Gender Essentialisms and Women’s Activism in Post-War BosniaHerzegovina." In Feminists Under Fire, ed. Wenona Giles et al. Toronto: Between the Lines, $181-98$.

- 2007. "'Politics Is a Whore': Women, Morality and Victimhood in Post-War BosniaHerzegovina.” In The New Bosnian Mosaic, ed. Xavier Bougarel, Elissa Helms, and Ger Duijzings. Aldershot: Ashgate. 
Honig, Bonnie. 1995. “Toward an Agonistic Feminism: Hannah Arendt and the Politics of Identity" In Feminist Interpretations of Hannah Arendt, ed. Bonnie Honig. University Park : Pennsylvania State University Press, 135-166.

Kotef, Hagar, and Merav Amir. 2007. “(En)Gendering Checkpoints: Checkpoint Watch and the Repercussions of Intervention." Signs: Journal of Women in Culture and Society 32 (4): $973-96$

— 2011. "Between Imaginary Lines: On Justifications of Violence, Cemented Checkpoints, and the Paradox of Successful Failure in the Occupied Palestinian Territories." Theory Culture and Society 28(1): 55-80.

Levi, Vered, 2007. "Being There," Haaretz. http://www.haaretz.co.il/hasite/pages/ShArtPE. jhtml?Item No = 811905 (accessed September 37, 2010).

Mansbach, Daniela. 2007. “The Power of Duality: The Protest of 'Checkpoint Watch.” Theory and Criticism 31: 77-99.

Maunaguru, Sitralega. 2009. "Gendering Tamil Nationalism: The Construction of 'Woman' in Projects of Protest and Control." In Unmaking the Nation, ed. Pardeep Jeganathan and Qadri Ismail. New York: South Focus, 157-73.

Molyneux, Maxine. 1985. "Mobilization without Emancipation? Women's Interests, the State, and Revolution in Nicaragua." Feminist Studies 11: 227-54.

Neugebauer, Monica E. 1998. "Domestic Activism and Nationalist Struggle." In The Women and War Reader, ed. Lois Ann Lorentzen and Jennifer Turpin. New York: New York University Press, 177-83.

Neuman, Tamara. 2004. "Maternal 'Anti-Politics' in the Formation of Hebron's Jewish Enclave." Journal of Palestine Studies 33 (2): 51-70.

OCHA (UN Office for the Coordination of Humanitarian Affairs). 2010. West Bank Closure Map. June. http://www.ochaopt.org/maps.aspx?id=106. (accessed: June 2011)

Ophir, Adi. 2002. "The Administration of Disaster and the Forsaking of Lives." Theory and Criticism 23: 67-104.

Orleck, Annelise. 1997. "Introduction." In The Politics of Motherhood, ed. Alexis Jetter et al. Hanover, NH: University Press of New England, 3-22.

Pateman, Carole. 1988. The Sexual Contract. Stanford: Stanford University Press.

Povinelli, Elizabeth. 2006. The Empire of Love: Toward a Theory of Intimacy. Durham, NC: Duke University Press.

Ruddick, Sarah. 1995. Maternal Thinking: Toward a Politics of Peace. Boston: Beacon.

Samuel, Kumudini. 2003. "Activism, Motherhood, and the State in Sri Lanka's Ethnic Conflict." In Feminists Under Fire, ed. Wenona Giles et al. Toronto: Between the Lines, $167-79$.

Setter, Shaul. 2007. "Sleeping with the Enemy? On Tali Fahima's Erotic Politics." Presented at Historicism, Homonormativity, and Queer Political Formations. University of California, Santa Cruz.

Sharoni, Simona. 1997. "Motherhood and the Politics of Women's Resistance: Israeli Women Organizing for Peace." In The Politics of Motherhood, ed. Alexis Jetter et al. Hanover, NH: University Press of New England, 144-60.

Sjoberg, Laura, and Caron E. Gentry. 2006. Mother Monsters, Whores: Women's Violence in Global Politics. New Yokr: Zen Books.

Sparks, Holloway. 1997. "Dissident Citizenship: Democratic Theory, Political Courage, and Activist Women." Hypatia. 12 (4): 74-110.

_ 2009. "Gender and the Politics of Democratic Disturbance in the Montgomery Bus Boycott." Presented at the Western Political Science Association Annual meeting, Vancouver (Canada).

Stoler, Ann. 1995. Race and the Education of Desire. Durham, NC: Duke University Press. 
Swerdlow, Amy. 1993. Women Strike for Peace: Traditional Motherhood and Radical Politics in the 1960s. Chicago: University of Chicago Press.

“Tali Fahima: Zakariya Zubeidi Is Israeli Security Service's Whore” 2008. Ha'aretz. http:// www.haaretz.com/news/tali-fahima-zakariya-zubeidi-is-israeli-security-service-s-whore-l . 285313 (last accessed September 27, 2010).

Tronto, Joan. 2008. "Is Peacekeeping Care Work? A Feminist Reflection on "The Responsibility to Protect."' In Global Feminist Ethic, ed. Rebecca Whisnam and Peggy DesAutels. New York: Rowman \& Littlefield.

Weizman, Eyal. 2007. Hollow Land: Israel's Architecture of Occupation. New York: Verso.

Zerilli, Linda. 2005. Feminism and the Abyss of Freedom. Chicago: University of Chicago Press. 